\title{
Characterization of a hybrid Li-ion anode system from pulsed laser deposited silicon on CVD-grown multilayer graphene
}

\author{
Gouri Radhakrishnan • Paul M. Adams • \\ Michael V. Quinzio
}

Received: 8 January 2014/ Accepted: 21 January 2014/Published online: 14 February 2014

(C) The Author(s) 2014. This article is published with open access at Springerlink.com

\begin{abstract}
A hybrid anode system for lithium (Li) ion battery applications based on pulsed laser deposited silicon films on chemical vapor deposited multilayer graphene (MLG) layers on a nickel foam substrate was electrochemically characterized. The as-grown material was directly fabricated into an anode without a binder, and tested in a half-cell configuration. There is evidence of the participation of both the multilayer graphene and the $\mathrm{Si}$ in the transport of Li ions. Even when cycled under stressful voltage limits that accelerate degradation, the MLG-Si films displayed higher stability than Si-only anodes, especially at higher cycling rates. Unlike the $\mathrm{Si}$ cells that display capacity fade even within the first few cycles, the MLG-Si cells show a very narrow spread in capacity, indicative of the role of the graphene layers in improving adhesion of the $\mathrm{Si}$ and acting as a compliant buffer for its volume expansion. Stable average specific capacities of $\sim 1,200 \mathrm{mAh} / \mathrm{g}$ per total weight of $\mathrm{MLG}+\mathrm{Si}$, over 80 cycles at $\mathrm{C} / 5$ rate, were obtained for the MLG-Si anode. Pre- and post-cycling characterization of the anode materials revealed the differences between the two systems.
\end{abstract}

\section{Introduction}

There is tremendous emphasis on the improvement of electrode materials for lithium (Li) ion batteries to meet the requirements of both high cycle life and storage

G. Radhakrishnan $(\bowtie) \cdot$ P. M. Adams · M. V. Quinzio Physical Sciences Laboratories, The Aerospace Corporation, Mail Station M2-242, P.O. Box 92957, Los Angeles, CA 90009, USA

e-mail: gouri.radhakrishnan@aero.org capacity. Continued interest had been directed toward silicon ( $\mathrm{Si}$ ) owing to its highest known capacity of $3,579 \mathrm{mAh} / \mathrm{g}$ [1] and addressing and overcoming the tremendous volume expansion in $\mathrm{Si}$ during $\mathrm{Li}$ insertion and extraction [2-5]. Approaches include the use of silicon thin films [6-12], nano and microwires [13-18], nanotubes [19], and nanoparticles [20-25]. Near theoretical specific capacities of $>3000 \mathrm{mAh} / \mathrm{g}$ were measured by the use of Si nanowires [15]. There is also a great deal of interest in combining silicon with different forms of carbon and this includes recent investigations on mixed graphene-silicon layers for improved capacity. The techniques reported include filtered liquid-phase exfoliated graphene films and coated with plasma-assisted chemical vapor deposition (PECVD) amorphous Si [26], electrophoretic deposition of graphene on $\mathrm{Cu}$ foil with $\mathrm{RF}$ sputtered amorphous Si [27], exfoliated graphite coated with both Si and C [28], and graphene-encapsulated Si nanoparticles on graphene foam [29]. Typical capacities reported by the above techniques, range from 1,000 to $2,000 \mathrm{mAh} / \mathrm{g}$, depending upon the cycling rates and normalization factors.

In previous work we have reported on the growth and material characterization of pulsed laser deposited (PLD) $\mathrm{Si}$ on multilayer graphene (MLG) [30]. This work aims at understanding the electrochemical performance of MLGPLD Si anodes. The substrate is nickel foam that has generated recent interest as a current collector, offers a porous and rough surface, as well as a large surface area $[31,32]$ in comparison to thin metal foils. There have only been a few reports on PLD films as anode materials and these have described thin Si films on $\mathrm{Cu}$ substrates [11, 12]. Here, we present a detailed electrochemical comparison of the MLG-PLD Si anode system with a PLD Si-only anode, which includes cyclic voltammetry, galvanostatic cycling 
at different rates and different Si thickness, and the effects of cycling voltage limits, all of which show evidence of the participation of MLG and its benefits. To the best of our knowledge, there are no prior reports on the detailed electrochemistry of the MLG-PLD Si system.

\section{Experimental}

Multilayer graphene was grown on $\mathrm{Ni}$ foam substrates (Goodfellow; $95 \%$ pure, $1.6 \mathrm{~mm}$ thick, $95 \%$ porosity, and $450 \mathrm{~kg} / \mathrm{m}^{3}$ bulk density) using the decomposition of methanol at $1,050{ }^{\circ} \mathrm{C}$, in a flow of pure $\mathrm{Ar}$ gas, without $\mathrm{H}_{2}$ [33]. Field emission scanning electron microscopy (FESEM) images of the foam [30] revealed its structure which consists of hollow struts that are $\sim 100 \mu \mathrm{m}$ wide with a wall thickness that varies from 10 to $20 \mu \mathrm{m}$. Details of the deposition process have been described in detail in an earlier work [33]. Following the growth of graphene, pulsed laser deposition was used to deposit $\mathrm{Si}$ on the MLG-coated Ni foam [30]. In brief, ablations were conducted at room temperature, in high vacuum at a pressure $<1 \times 10^{-7}$ torr, using focused $\mathrm{KrF}$ laser radiation at $248 \mathrm{~nm}$, at $20 \mathrm{~Hz}$, and with a typical fluence of $15-16 \mathrm{~J} / \mathrm{cm}^{2}$. The estimated rate of deposition was $0.04 \mu \mathrm{g} / \mathrm{laser}$ pulse. Deposition times were varied to attain different weights of Si. TEM cross section revealed an average Si thickness of $550 \mathrm{~nm} / \mathrm{mg}$ of Si deposited. The foam was weighed both before and after MLG and Si depositions. For the MLG-Si anodes, the specific capacity was calculated both per weight of Si and per combined weight of MLG and Si.

For establishing the number of graphene layers on the $\mathrm{Ni}$ substrate, as well as the thickness and crystallinity of the $\mathrm{Si}$ films, a cross-sectional sample was prepared for transmission electron microscopy (TEM) by conventional focused ion beam (FIB) lift-out methods [33, 34]. High-resolution TEM was conducted in a Hitachi H9000-NAR TEM at $300 \mathrm{keV}$.

Raman spectra were measured using a Renishaw inVia Micro Raman Spectrometer operating at $514 \mathrm{~nm}$ laser excitation (laser power was $0.8-0.9 \mathrm{~mW}$ ).

Anodes were fabricated directly from the PLD MLG-Si on $\mathrm{Ni}$ and the PLD Si on Ni without using any binder and used in a 2032 coin cell. The anodes were tested by cycling the electrode in a half-cell configuration versus $\mathrm{Li}$ metal using $1 \mathrm{M} \mathrm{LiPF}_{6}$ in 1:1 ethylene carbonate/diethyl carbonate (EC/DEC) electrolyte. Galvanostatic cycling and cyclic voltammetry were performed using Keithley 2400 Source Meters and an Arbin BT2000 cycler. After cycling, cells were discharged before opening, and the anodes were rinsed in DEC and vacuum dried prior to post-cycling characterization.

\section{Results and discussion}

\subsection{Microscopy and Raman Spectroscopy}

Following MLG deposition on the foam, contrast can be observed in the FESEM image (Fig. 1a), and the surface changes markedly following the addition of PLD Si on top of the MLG (Fig. 1b). Small scattered and isolated particulates or nodules can be seen on the PLD Si and these are due to ejection of molten droplets of Si created by the ablation process that re-solidify upon arrival on the substrate surface.

In Fig. 1c, a crystalline $\mathrm{Si}$ (c-Si) nodule embedded in the amorphous $\mathrm{Si}(\mathrm{a}-\mathrm{Si})$ is imaged by cross-sectional TEM. The crystallinity is evident from diffraction contrast and was confirmed with a selected area diffraction (SAED) pattern (Fig. 1d). The image shows the overall thickness of the amorphous Si film layer was $\sim 100 \mathrm{~nm}$ in this sample; however, the isolated particulates of crystalline $\mathrm{Si}$ were in the order of $400-500 \mathrm{~nm}$. Also seen in the image is the diffraction contrast of the graphene layer beneath the amorphous Si layer. From a high-resolution TEM cross section, reported elsewhere [30], the graphene thickness was measured at $23 \mathrm{~nm}$, which corresponds to $\sim 68$ layers. The average graphitic layer spacing was measured at $0.338 \mathrm{~nm}$ (from fast Fourier Transforms) after calibration to $\mathrm{Ni}(111)$ at $0.204 \mathrm{~nm}$.

The growth of multilayer graphene films with very low disorder was confirmed, as indicated by the D band at $1,360 \mathrm{~cm}^{-1}$ in the Raman spectrum (Fig. 2a). The Si films were a combination of crystalline and amorphous. The crystallinity was very specific to particulates ejected from the ablated target that were co-deposited with the growing film. Raman spectra taken at different spatial locations (Fig. 2b) showed a 1:1 correspondence between the presence of particulates and increasing intensity of the peak at $520 \mathrm{~cm}^{-1}$ due to crystalline Si. The broad peak centered around $480 \mathrm{~cm}^{-1}$ was characteristic of amorphous $\mathrm{Si}$ present as the primary component and represented by smooth areas of the Si film.

\subsection{Electrochemical measurements}

\subsubsection{Cyclic voltammetry}

Cyclic voltammetry was performed in the range $0.01-3.0 \mathrm{~V}$ at a scan rate of $25 \mu \mathrm{V} / \mathrm{s}$. It must be noted that voltammetry was conducted following galvanostatic measurements for a few cycles each at $\mathrm{C} / 10, \mathrm{C} / 5$, and $\mathrm{C} / 2$ hence these peaks are not representative of the first cycle. Figures 3 a-d shows the voltammograms of $\mathrm{Ni}$ foam, MLG-Ni, PLD Si-Ni, and PLD MLG-Si-Ni, respectively. Cycled MLG-Ni (Fig. 3b) showed a distinct intercalation 




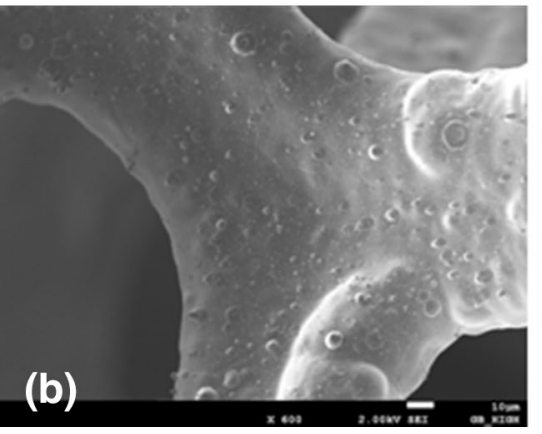

Fig. 1 FESEM images of Ni foam after MLG deposition (a), and after PLD Si growth on MLG (b). Cross-sectional TEM image of an isolated crystalline Si nodule located on top of an amorphous Si layer (c). It should be noted that at locations away from nodules the $\mathrm{Si}$ is (c)

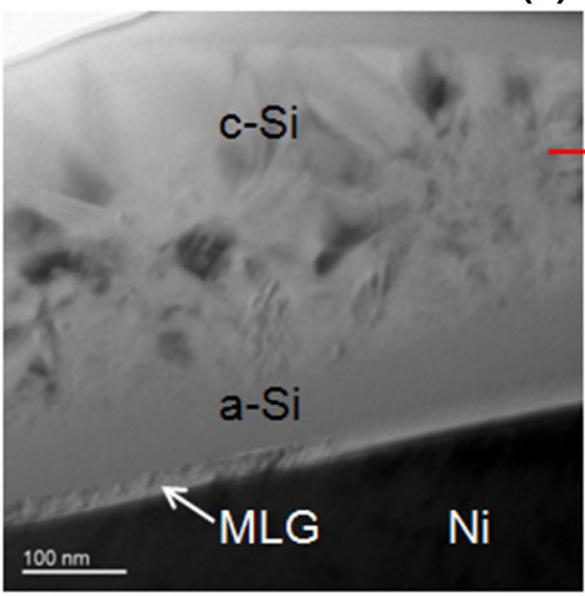

amorphous. Diffraction contrast from graphene is seen below the amorphous $\mathrm{Si}$. SAED pattern of the $\mathrm{c}-\mathrm{Si}$, as indicated by arrow is shown to the right $(\mathbf{d})$
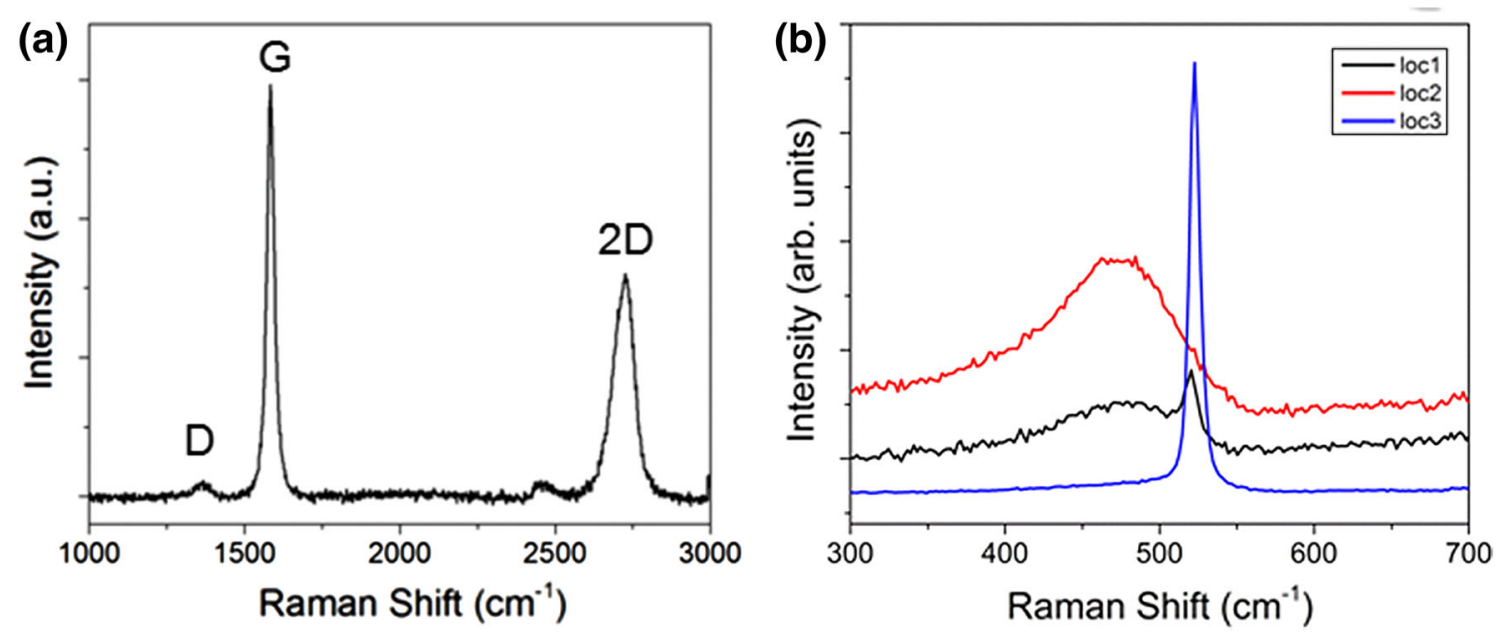

Fig. 2 Raman spectra of as-deposited MLG on Ni foam (a) and PLD silicon on MLG at different locations (b)

peak at $0.059 \mathrm{~V}$ and a small shoulder at $0.085 \mathrm{~V}$, which are characteristic of the intercalation Stages I and II of Li into graphite [35], and corresponding deintercalation peaks at 0.089 and $0.123 \mathrm{~V}$. PLD Si shows intercalation peaks at 0.212 and $0.068 \mathrm{~V}$ and deintercalation peaks at 0.297 and $0.459 \mathrm{~V}$ (Fig. 3c). The peak at $0.212 \mathrm{~V}$ is due to highvoltage lithiation of a-Si [6] while the peak appearing at $0.068 \mathrm{~V}$ may be a combination of the low-voltage peak due to a-Si at $0.100 \mathrm{~V}$ and the crystallization of the $\mathrm{Li}_{15} \mathrm{Si}_{4}$ phase at $0.030 \mathrm{~V}[1,2,4]$. Delithiation peaks at 0.297 and $0.459 \mathrm{~V}$ can be attributed to the low-voltage and highvoltage delithiation plateaus of a-Si, respectively [4]. For the PLD MLG-Si anode (Fig. 3d), cyclic voltammetry shows peaks that are characteristic of $\mathrm{Si}$, as well as small but well-defined peaks due to the graphene layers $(0.090$ and $0.139 \mathrm{~V}$ ). In addition, a lithiation peak at $0.210 \mathrm{~V}$ is observed, due to a-Si. Another peak $\leq 0.02 \mathrm{~V}$ is also measured, whose assignment is not certain. Expanded plots 

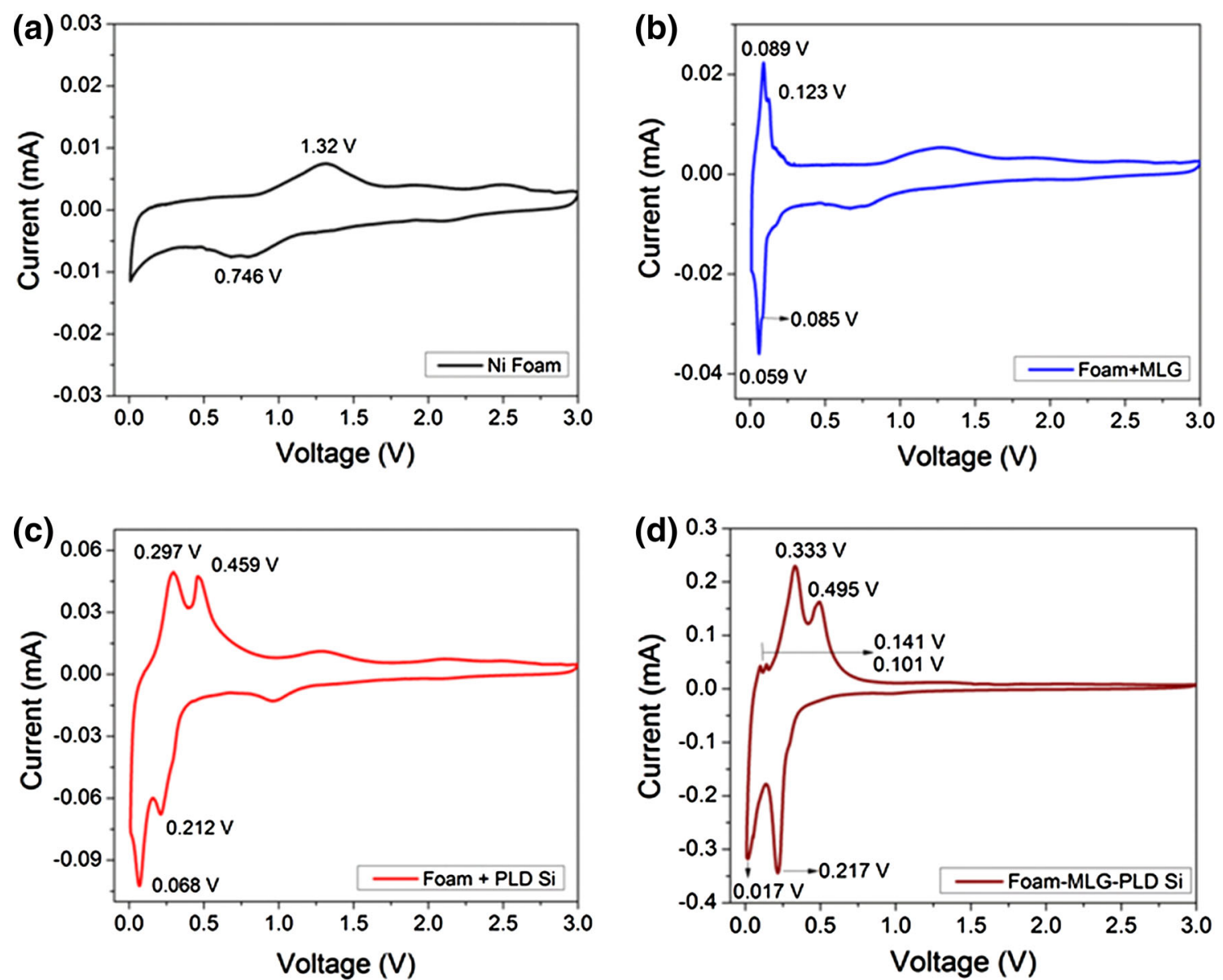

Fig. 3 Cyclic voltammograms performed on Ni foam (a), MLG on Ni foam (b), PLD Si on Ni foam (c), and PLD Si on MLG on Ni foam (d)

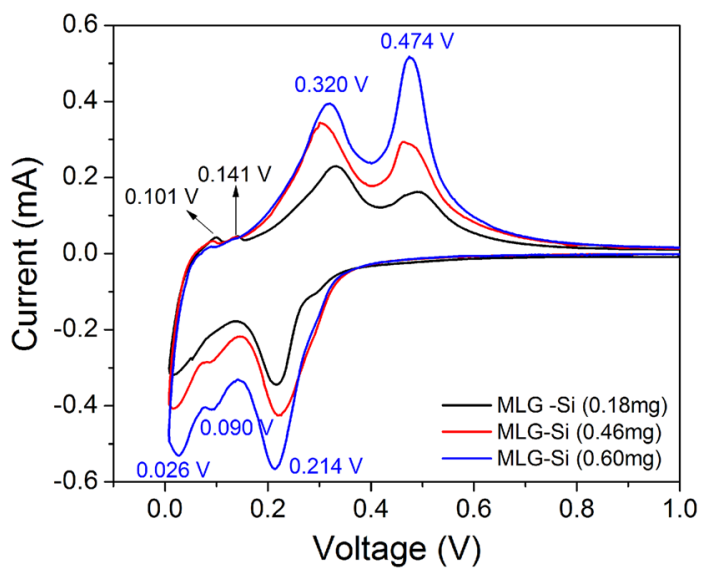

Fig. 4 Cyclic voltammograms performed on MLG-Si anodes with varying weights of PLD Si, highlighting the range from 0.01 to $1.0 \mathrm{~V}$

for MLG-Si in the range $0.01-1.0 \mathrm{~V}$ are shown in the following Fig. 4.

Cyclic voltammetry on the MLG-Si anode was also conducted as a function of $\mathrm{Si}$ weight in the combination.
Figure 4 shows that the increase in the lithiation and delithiation peak intensities of Si clearly follows the increase in Si layer thickness/weight. Lithiation and delithiation potentials are indicated for the outermost curve; however, small shifts in peak positions are observed in the three curves. It is also observed that the $\mathrm{Si}$ is the dominant electrochemical participant relative to MLG as seen from their relative peak heights. The MLG delithiation peaks at 0.101 and $0.141 \mathrm{~V}$ are clearly resolved at the lower $\mathrm{Si}$ weights, but unresolvable at the highest $\mathrm{Si}$ weight of $0.60 \mathrm{mg}$. In addition to lithiation peaks at 0.214 and $0.090 \mathrm{~V}$, this curve also shows an additional peak at $0.026 \mathrm{~V}$, which is likely due to the crystallization of the $\mathrm{Li}_{15} \mathrm{Si}_{4}$ phase $[1,2,4]$. This differs from findings with PLD $\mathrm{Si}$ films on $\mathrm{Cu}$ where no evidence for the $\mathrm{Li}_{15} \mathrm{Si}_{4}$ phase below $0.05 \mathrm{~V}$ was observed [12].

\subsubsection{Galvanostatic Cycling}

Galvanostatic charge and discharge cycles were performed to test the capacity and cyclic stability of the cells between 0.01 and $3.0 \mathrm{~V}$, at different rates $(\mathrm{C} / 10$ to $\mathrm{C} / 1.5)$. 

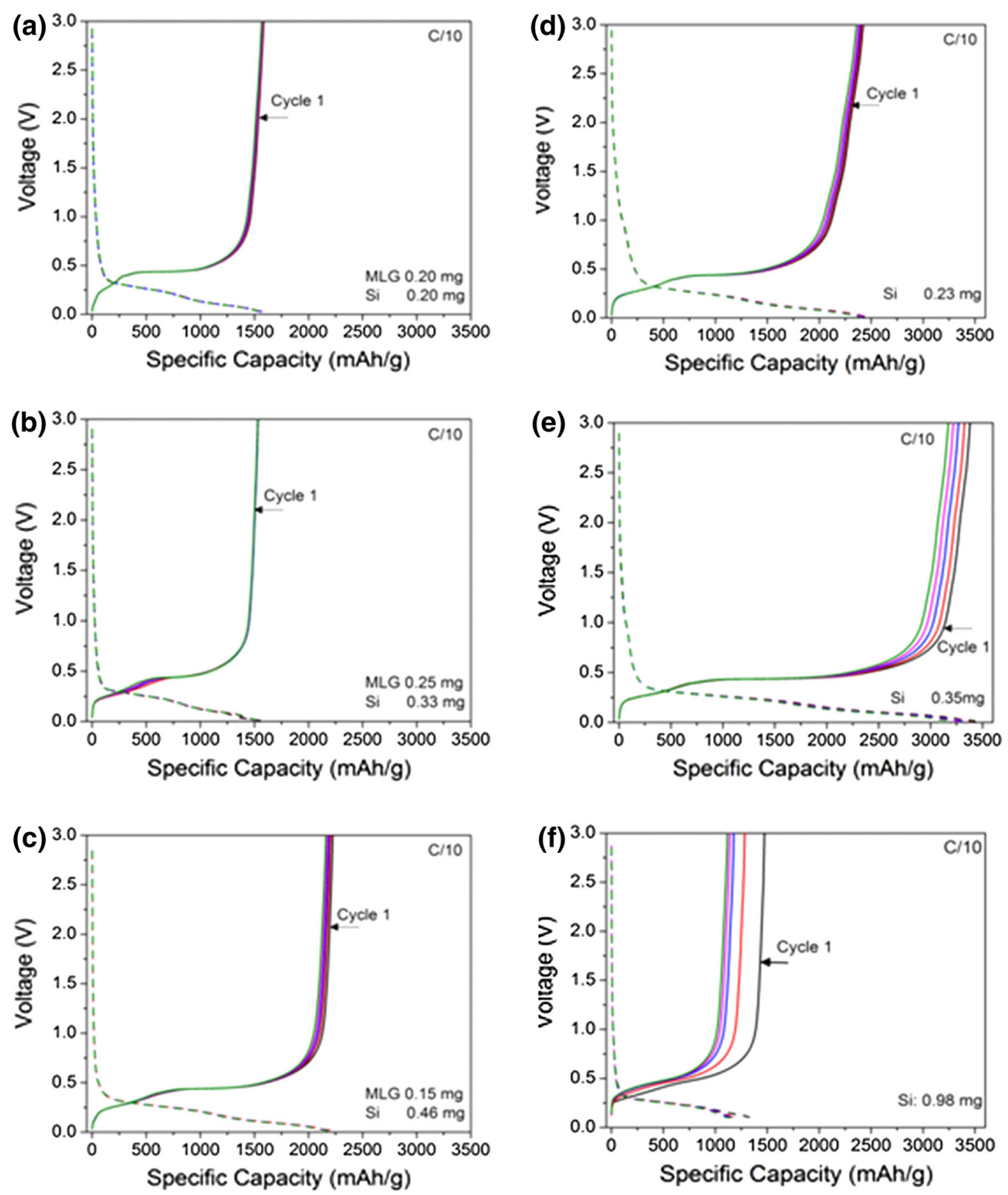

Fig. 5 Cycling performances at $\mathrm{C} / 10$ rate for anodes with different Si weights. Left column $(\mathbf{a}, \mathbf{b}, \mathbf{c})$ shows data for MLG-Si anodes and right column $(\mathbf{d}, \mathbf{e}, \mathbf{f})$ shows data for $\mathrm{Si}$-only anodes. The specific

These voltage limits present a more stressful condition than the more typically used range, $0.05-1.0 \mathrm{~V}$, and therefore provided an accelerated test condition. The lower voltage limit also allowed us to investigate the effects of both the crystalline and amorphous components of Si. Some of the cells were also subjected to 100 cycles at $\mathrm{C} / 2$ or $\mathrm{C} / 1.5$.

capacity of the MLG-Si anode was calculated using the combined weight of Si plus MLG

Shown in Fig. 5 is a comparison of the first five cycles of Si cells with different weights, with and without MLG, cycled at $\mathrm{C} / 10$ rate. Note that in all cases, the specific capacity of the $\mathrm{Si}$ anodes is calculated using the weight of $\mathrm{Si}$, while that of the MLG-Si anodes is calculated using the combined weight of MLG and Si. This results in a lower "specific" capacity for the MLG-Si system. If 
Table 1 1st cycle specific capacities at different $\mathrm{C}$ rates: MLG-Si and $\mathrm{Si}$ anodes

\begin{tabular}{|c|c|c|c|c|c|c|}
\hline \multirow{2}{*}{$\begin{array}{l}\text { Cycling rate } \\
\text { All at } 0.01-3.0 \mathrm{~V}\end{array}$} & \multicolumn{2}{|c|}{ Wt. of MLG-Si (mg) } & \multicolumn{2}{|c|}{ Specific capacity of MLG-Si anode $(\mathrm{mAh} / \mathrm{g})$} & \multirow[t]{2}{*}{ Wt. of $\mathrm{Si}(\mathrm{mg})$} & \multirow{2}{*}{$\begin{array}{l}\text { Specific capacity } \\
\text { of } \mathrm{Si} \text { anode }(\mathrm{mAh} / \mathrm{g}) \\
\text { Per Si weight }\end{array}$} \\
\hline & MLG (mg) & $\mathrm{Si}(\mathrm{mg})$ & Per MLG + Si weight & Per Si weight & & \\
\hline \multirow[t]{4}{*}{$\mathrm{C} / 10$} & 0.20 & 0.20 & 1,588 & 3,176 & 0.23 & 2,444 \\
\hline & 0.25 & 0.33 & 1,490 & 2,620 & 0.35 & 3,380 \\
\hline & 0.15 & 0.46 & 2,223 & 2,948 & & \\
\hline & & & & & 0.98 & 1,472 \\
\hline $\mathrm{C} / 5$ & 0.25 & 0.33 & 1,403 & 2,466 & 0.35 & 2,882 \\
\hline $\mathrm{C} / 3$ & 0.14 & 0.18 & 1,524 & 2,709 & 0.12 & 1,921 \\
\hline $\mathrm{C} / 2$ & 0.25 & 0.33 & 1,111 & 1,953 & 0.35 & 2,218 \\
\hline
\end{tabular}

For the MLG-Si anodes specific capacities with respect to combined MLG $+\mathrm{Si}$ weights as well as by only the Si weight are listed
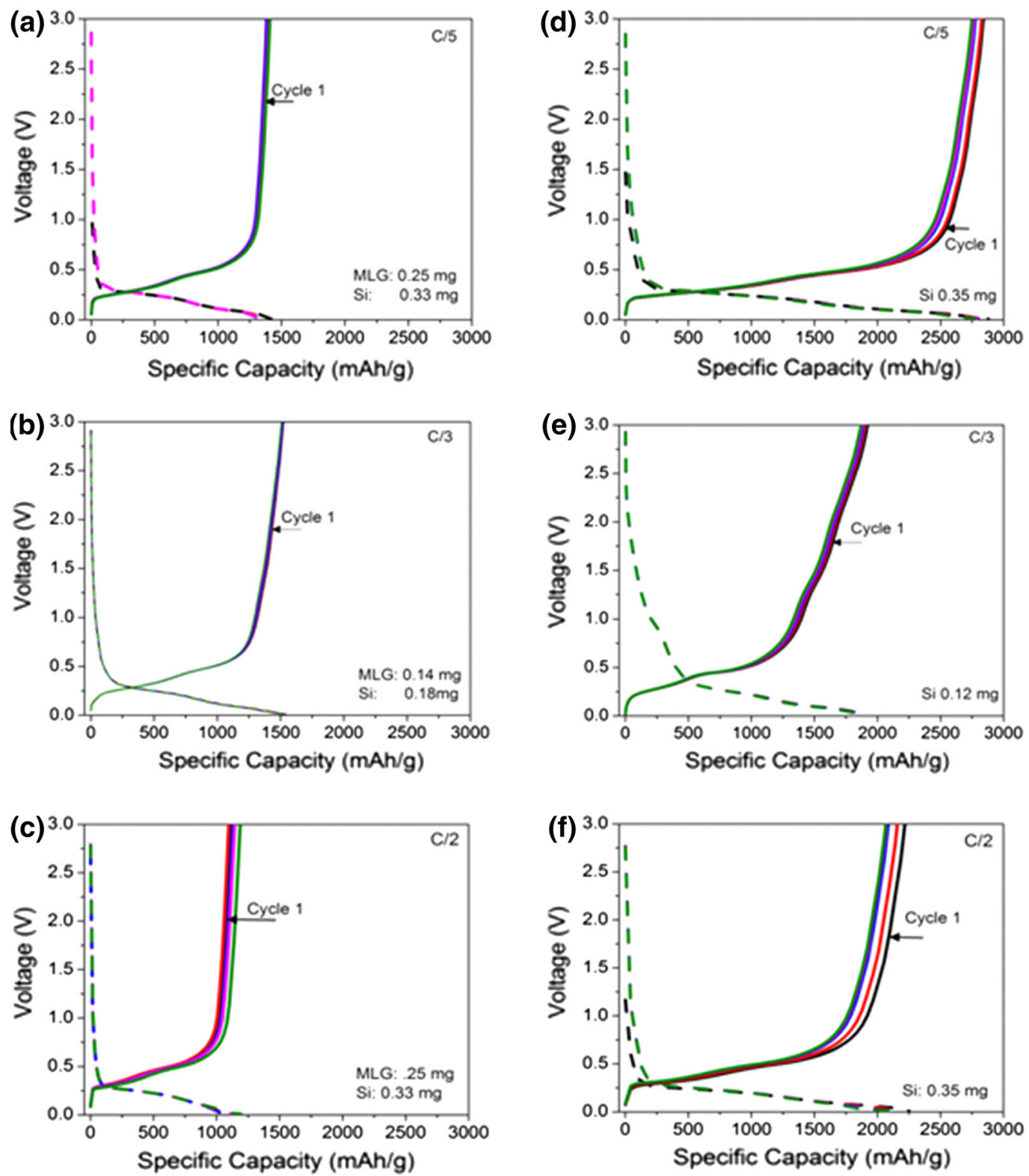

Fig. 6 Cycling performance at C/5, C/3, and C/2 rates; PLD MLG-Si (a-c) and PLD Si (d-f). The specific capacity of the MLG-Si anode was calculated using the combined weight of Si plus MLG 


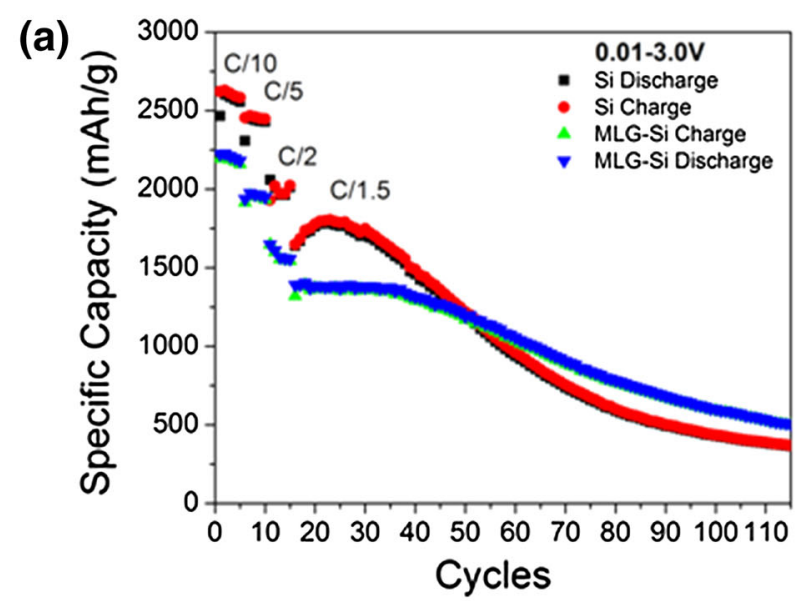

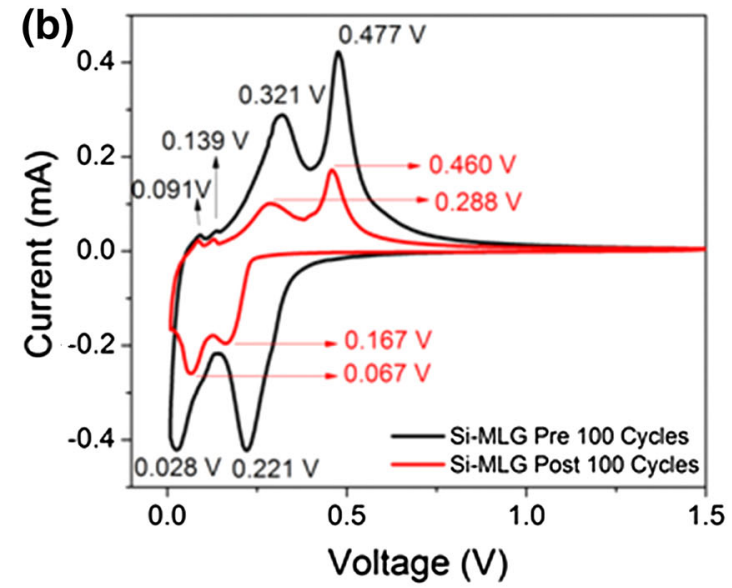

Fig. 7 Comparison of cycling performance curves of MLG-Si and $\mathrm{Si}$ at different rates (a). The specific capacity of the MLG-Si anode was calculated using the combined weight of Si plus MLG. Cyclic

calculated only using the weight of $\mathrm{Si}$, the MLG-Si specific capacities are comparable to those of the $\mathrm{Si}$ anodes. These values are listed in Table 1. It is clearly observed that the MLG-Si cells (Fig. 5a-c) show a very tight spread in capacity, while the Si-only cells (Fig. 5df) show capacity fade. As the $\mathrm{Si}$ weight is increased in the range $0.2-0.4 \mathrm{mg}$, cell capacity initially increases (Fig. 5d, e). However, we found that increasing the Si by nearly a factor of five (Fig. 5f) is detrimental to the capacity and the capacity fade becomes very significant. Even the MLG-Si cells (Fig. 5c) start to show some fade when the $\mathrm{Si}$ exceeds $0.4 \mathrm{mg}$, although this fade is still small compared to the Si-only cells. At higher cycling rates, capacity fade becomes more evident in both systems as shown in Fig. 6, but the Si-only cells show significantly more fading (Fig. 6d-f) than the MLG-Si cells (Fig. 6a-c).

A comparison of cycling performance of two Si cells with and without MLG, in the range $0.01-3.0 \mathrm{~V}$, is shown below (Fig. 7a). The cells comprised a $\mathrm{Si}$ cell

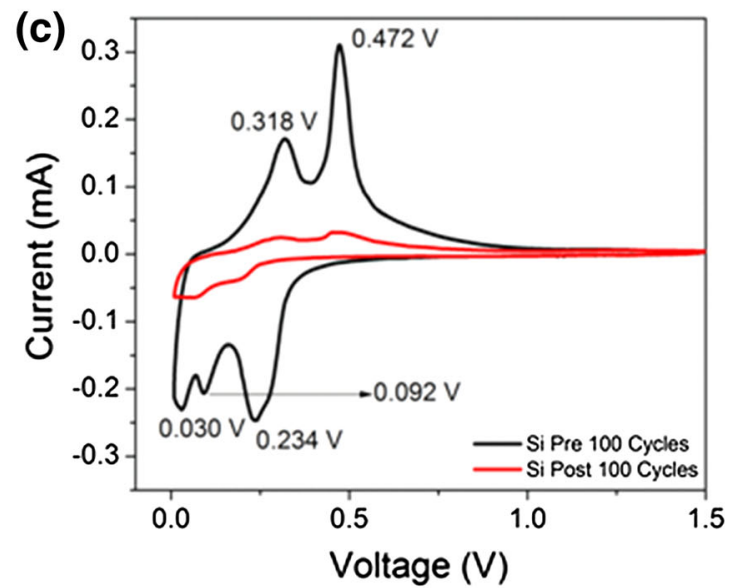

voltammograms of MLG-Si (b) and PLD Si (c) anodes, pre- and post100 cycles at $\mathrm{C} / 1.5$

with $0.33 \mathrm{mg} \mathrm{Si}$, and an MLG-Si cell with $0.15 \mathrm{mg}$ MLG and $0.46 \mathrm{mg} \mathrm{Si}$. They were initially cycled for five cycles each at $\mathrm{C} / 10, \mathrm{C} / 5$, and $\mathrm{C} / 2$, and then cycled at $\mathrm{C} / 1.5$ for 100 cycles. Although neither cell performed very well under these cycling conditions of high rate and cycling to $0.01 \mathrm{~V}$, performance of the MLG-Si cell was significantly better than the $\mathrm{Si}$ cell with very stable capacity for the first 30 of 100 cycles at C/1.5. In contrast, the Si-only cell showed a continuous decline after an initial increase over the first five cycles. After 45 cycles, the MLG-Si anodes still showed $87 \%$ of its starting capacity at $\mathrm{C} / 1.5$, but the $\mathrm{Si}$ anode had degraded to $70 \%$. At the end of 100 cycles, the capacity of the $\mathrm{Si}$ cell was reduced to $22 \%$ of its initial capacity at $\mathrm{C} / 1.5$ of $1,638 \mathrm{mAh} / \mathrm{g}$ and that of the MLG-Si anode was reduced to $38 \%$ of its initial capacity of $1,321 \mathrm{mAh} / \mathrm{g}$ at C/1.5.

Cyclic voltammetry at the rate of $25 \mu \mathrm{V} / \mathrm{s}$ was performed both before and after 100 cycles at $\mathrm{C} / 1.5$ on the MLG-Si and $\mathrm{Si}$ cells described above (Fig. $7 \mathrm{~b}, \mathrm{c}$ ). It 


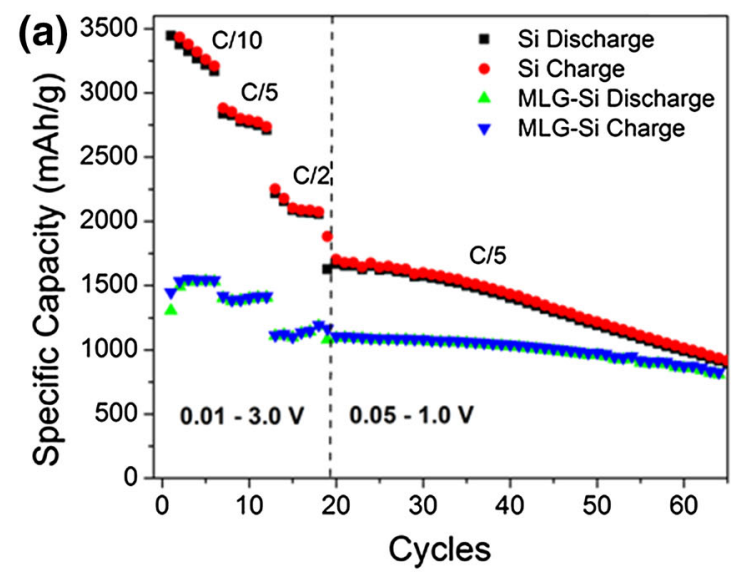

Fig. 8 Comparison of specific capacity as a function of number of cycles for MLG-Si and $\mathrm{Si}$ under different testing voltages. The cells in (a) were cycled initially at $\mathrm{C} / 10, \mathrm{C} / 5$, and $\mathrm{C} / 2$ at $0.01-3.0 \mathrm{~V}$, and

was observed that after cycling, intercalation and deintercalation peaks from Si had decreased in intensity but were clearly measurable (post-cycling deintercalation peaks at 0.288 and $0.460 \mathrm{~V}$ ) in the MLG-Si anodes (Fig. 7a). In addition, distinct graphitic deintercalation peaks $(0.091$ and $0.139 \mathrm{~V})$ were still clearly observed from MLG. In contrast, the Si peaks in the bare Si anodes had decreased very substantially (Fig. 7b). These results are consistent with measured loss of capacity in both

Table 2 1st cycle specific capacities of MLG-Si and $\mathrm{Si}$ anodes at different cycling and test voltage conditions corresponding to plots in Figs. 7a, 8a, b, respectively. For the MLG-Si anodes specific capacities with respect to combined MLG $+\mathrm{Si}$ weights as well as

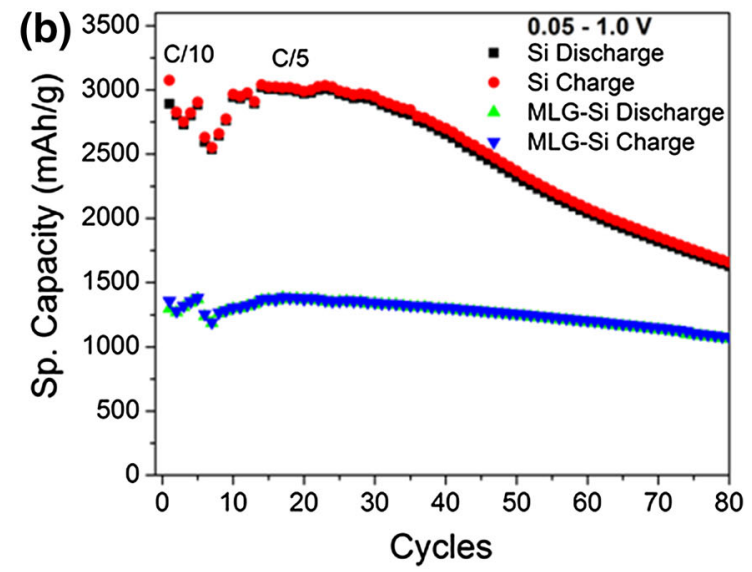

thereafter at $\mathrm{C} / 5$ at $0.05-1.0 \mathrm{~V}$. The cells in $(\mathbf{b})$ were cycled at $\mathrm{C} / 10$ and $\mathrm{C} / 5$ both at $0.05-1.0 \mathrm{~V}$. The specific capacity of the MLG-Si anode was calculated using the combined weight of Si plus MLG

systems, and a more significant one with the Si-only anode.

Results for cycling at $0.01-3.0 \mathrm{~V}$ clearly show that MLG does help to reduce capacity fading. In addition, the initial specific capacity is quite good. Even when cycled at high rates such as C/1.5, the MLG-Si retained $87 \%$ of its initial capacity for 45 cycles, but thereafter showed degradation under these conditions. To investigate ways of extending stable cycle life, which is desired for many

only the Si weight are listed. 1st and last cycle (hyphenated) specific capacities are listed for the extended cycling with corresponding capacity retention in parentheses

\begin{tabular}{|c|c|c|c|c|}
\hline \multirow[t]{2}{*}{ Cycling voltage } & \multirow[t]{2}{*}{$\mathrm{C}$ rate } & \multicolumn{2}{|c|}{ Specific capacity of MLG-Si anode } & \multirow{2}{*}{$\begin{array}{l}\text { Specific capacity of Si anode } \\
\text { Per Si weight }\end{array}$} \\
\hline & & Per MLG + Si weight & Per Si weight & \\
\hline Condition I & & MLG $0.15 \mathrm{mg}$, Si $0.46 \mathrm{n}$ & & Si $0.33 \mathrm{mg}$ \\
\hline $0.01-3.0 \mathrm{~V}$ & $\mathrm{C} / 10$ & 2,223 & 2,948 & 2,621 \\
\hline $0.01-3.0 \mathrm{~V}$ & $\mathrm{C} / 5$ & 1,938 & 2,571 & 2,454 \\
\hline $0.01-3.0 \mathrm{~V}$ & $\mathrm{C} / 2$ & 1,647 & 2,185 & 2,060 \\
\hline \multirow[t]{3}{*}{$0.01-3.0 \mathrm{~V}$} & $\mathrm{C} / 1.5$ & & & \\
\hline & 45 cycles & $1,321-1,148(86.9 \%)$ & $1,752-1,523(86.9 \%)$ & $1,638-1,145(69.9 \%)$ \\
\hline & 100 cycles & $1,321-495(37.5 \%)$ & $1,751-657(37.5 \%)$ & $1,638-364(22.2 \%)$ \\
\hline Condition II & & MLG $0.25 \mathrm{mg}$, Si $0.33 \mathrm{n}$ & & Si $0.35 \mathrm{mg}$ \\
\hline $0.01-3.0 \mathrm{~V}$ & $\mathrm{C} / 10$ & 1,490 & 2,620 & 3,380 \\
\hline $0.01-3.0 \mathrm{~V}$ & $\mathrm{C} / 5$ & 1,403 & 2,466 & 2,882 \\
\hline $0.01-3.0 \mathrm{~V}$ & $\mathrm{C} / 2$ & 1,119 & 1,953 & 2,218 \\
\hline \multirow[t]{2}{*}{$0.05-1.0 \mathrm{~V}$} & $\mathrm{C} / 5$ & & & \\
\hline & 45 cycles & $1,082-809(74.8 \%)$ & $1,901-1,422(74.8 \%)$ & $1,626-915(56.3 \%)$ \\
\hline Condition III & & MLG $0.24 \mathrm{mg}$, Si $0.23 \mathrm{n}$ & & Si $0.19 \mathrm{mg}$ \\
\hline $0.05-1.0 \mathrm{~V}$ & $\mathrm{C} / 10$ & 1,300 & 2,656 & 2,892 \\
\hline \multirow[t]{2}{*}{$0.05-1.0 \mathrm{~V}$} & $\mathrm{C} / 5$ & & & \\
\hline & 80 cycles & $1,239-1,036(83.6 \%)$ & $2,533-2,117(83.6 \%)$ & $2,595-1,532(59.0 \%)$ \\
\hline
\end{tabular}





Fig. 9 Selected charge-discharge cycles from 45 cycles at $\mathrm{C} / 5$ at 0.05-1.0 V of MLG-Si anodes (a) and Si-only anodes (b). These cycles followed an initial set of cycles at a low rate, followed by cycling at $\mathrm{C} / 10, \mathrm{C} . / 5$, and $\mathrm{C} / 2$, all conducted at 0.01-3.0 V. Selected

charge-discharge cycles from 80 cycles at $\mathrm{C} / 5$ at $0.05-1.0 \mathrm{~V}$ without any prior cycling at $0.01-3.0 \mathrm{~V}$ of MLG-Si anodes (c) and Si-only anodes (d). The specific capacity of the MLG-Si anodes was calculated using the combined weight of Si plus MLG

applications, the effect of cycling conditions on different cells was compared by varying the voltage ranges. Shown below are two examples of pairs of cells with each pair having equivalent weights of $\mathrm{Si}$, with and without MLG (Fig. 8).

The first pair of cells (Fig. 8a) comprised an MLGSi system of 0.25 and $0.33 \mathrm{mg}$, respectively, and a Sionly cell with $0.35 \mathrm{mg}$ of $\mathrm{Si}$. This set was subjected to ten conditioning cycles initially at a low rate of $\mathrm{C} / 14$ at $0.01-3.0 \mathrm{~V}$, followed by six cycles each at $\mathrm{C} / 10, \mathrm{C} / 5$, and $\mathrm{C} / 2$ also at $0.01-3.0 \mathrm{~V}$, followed by additional cycling at $\mathrm{C} / 5$ at $0.05-1.0 \mathrm{~V}$. After 45 cycles at $\mathrm{C} / 5$ $(0.05-1.0 \mathrm{~V})$, the $\mathrm{Si}$ cell had dropped to $56 \%$ of its starting capacity of $1,626 \mathrm{mAh} / \mathrm{g}$. In contrast, at the end of 45 cycles the MLG-Si cell had only dropped to $75 \%$ of its initial capacity of $1,082 \mathrm{mAh} / \mathrm{g}$. However, since these cells had already been subjected to 0.01-3.0 V for several cycles, the effects of subsequently reducing the voltage limits are measurable but not as effective as limiting the voltages from the start, as described below.

The second set of cells that were selected (Fig. 8b) comprised an MLG-Si system of 0.24 and $0.23 \mathrm{mg}$, respectively, and a Si-only cell with $0.19 \mathrm{mg}$ of $\mathrm{Si}$. These cells were cycled exclusively in the range $0.05-1.0 \mathrm{~V}$, for five cycles at $\mathrm{C} / 10$, followed by cycling at $\mathrm{C} / 5$. In this case, it took 80 cycles for the $\mathrm{Si}$ cell to drop to $59 \%$ of its starting capacity of $2,595 \mathrm{mAh} / \mathrm{g}$ at $\mathrm{C} / 5$. The MLG-Si cell on the other hand was at $84 \%$ of its starting capacity of $1,239 \mathrm{mAh} / \mathrm{g}$ upon completion of 80 cycles. Hence, cycling under reduced voltage limits from the start offers a significant improvement in cycle life.

The cycling specific capacities for the Si and MLG-Si anodes tested under different $\mathrm{C}$ rates and testing voltages are summarized in Table 2. The specific capacity is also a function of the amount of $\mathrm{Si}$ in the sample. As pointed out earlier, higher Si weights yield higher capacities initially, but they degrade faster.

Select charge-discharge cycles corresponding to the 45 cycles shown in Fig. 8a are compared for the MLG-Si (Fig. 9a) and the Si-only (Fig. 9b) and clearly reveal the 

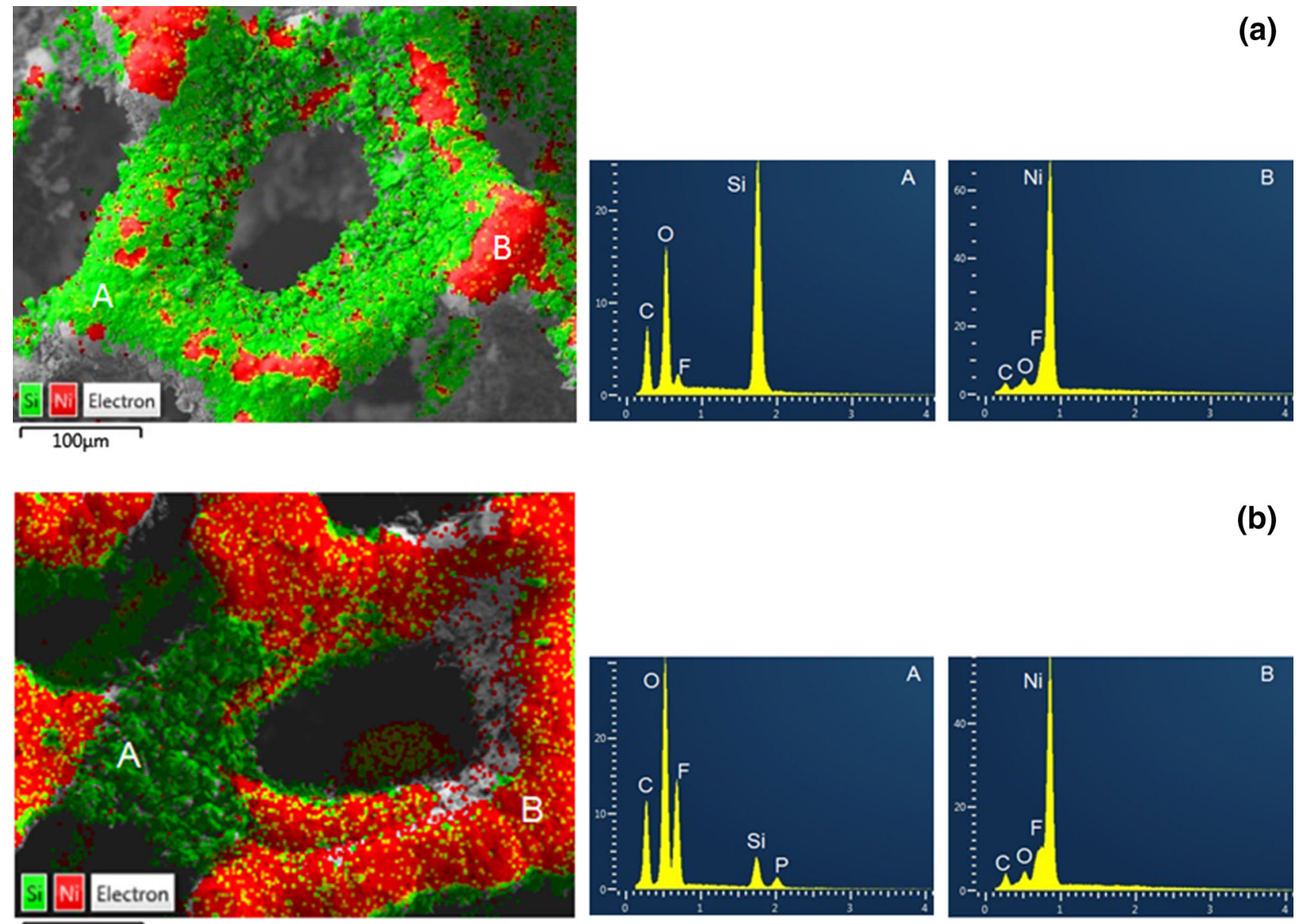

$100 \mu \mathrm{m}$

Fig. 10 Post-cycling FESEM images with EDS overlays following a total of 73 cycles under different rates as described in the text; MLG-Si (a) and Si-only (b). Green areas correspond to the presence of Si (as detected by EDS) and red areas correspond to the exposed Ni substrate

capacity fade of the Si-only cell. Figure 9c, d shows comparisons of select charge-discharge cycles corresponding to 80 cycles shown in Fig. 8b. As can be seen, there is a striking difference between the capacity fade of the MLG-Si (Fig. 9c) and the Si-only (Fig. 9d) cells over 80 cycles. In all cases, the effect of MLG in reducing capacity fade is clearly demonstrated.

These results clearly demonstrate that the MLG-Si system displayed superior performance compared to Sionly cells when subjected to the same cycling conditions. Incorporating MLG with the $\mathrm{Si}$ measurably reduces capacity fade and extends cycle life even when cycling at a voltage range above $0.05 \mathrm{~V}$ to avoid the crystallization of $\mathrm{Li}_{15} \mathrm{Si}_{4}[1,2,4]$.

\subsubsection{Post-cycling microscopy and Raman spectroscopy}

Post-cycling FESEM images of the MLG-Si and Si-only anodes described in Fig. 8a, with corresponding chargedischarge curves in Fig. 9a, b show a significant difference between the surfaces of the two systems (Fig. 10). The cells were opened following a total of 73 cycles under different rates as described in the previous section. The concentrations of $\mathrm{Si}$ and $\mathrm{Ni}$ are mapped here with energy dispersive spectroscopy (EDS) with the Si map shown in green and the Ni map in red. Although cracks and some delamination are observed in the MLG-Si anodes, the material appears to be still intact as seen by the overall coverage of Si on the surface (Fig. 10a). In contrast, severe delamination is observed in the Si-only anodes as confirmed by EDS (Fig. 10b).

We infer that the MLG provides improved adhesion of the $\mathrm{Si}$, can itself act as a conductive platform, and also acts as a buffer for the high-volume expansion of the Si. Bare $\mathrm{Si}$ on the other hand can lose electrical contact to the current collector upon cracking resulting in capacity fade, followed by complete loss of capacity from delamination.

In areas that showed the presence of $\mathrm{Si}$, high levels of $\mathrm{C}$, $\mathrm{O}$, and $\mathrm{F}$ were also detected by EDS. These are most likely 

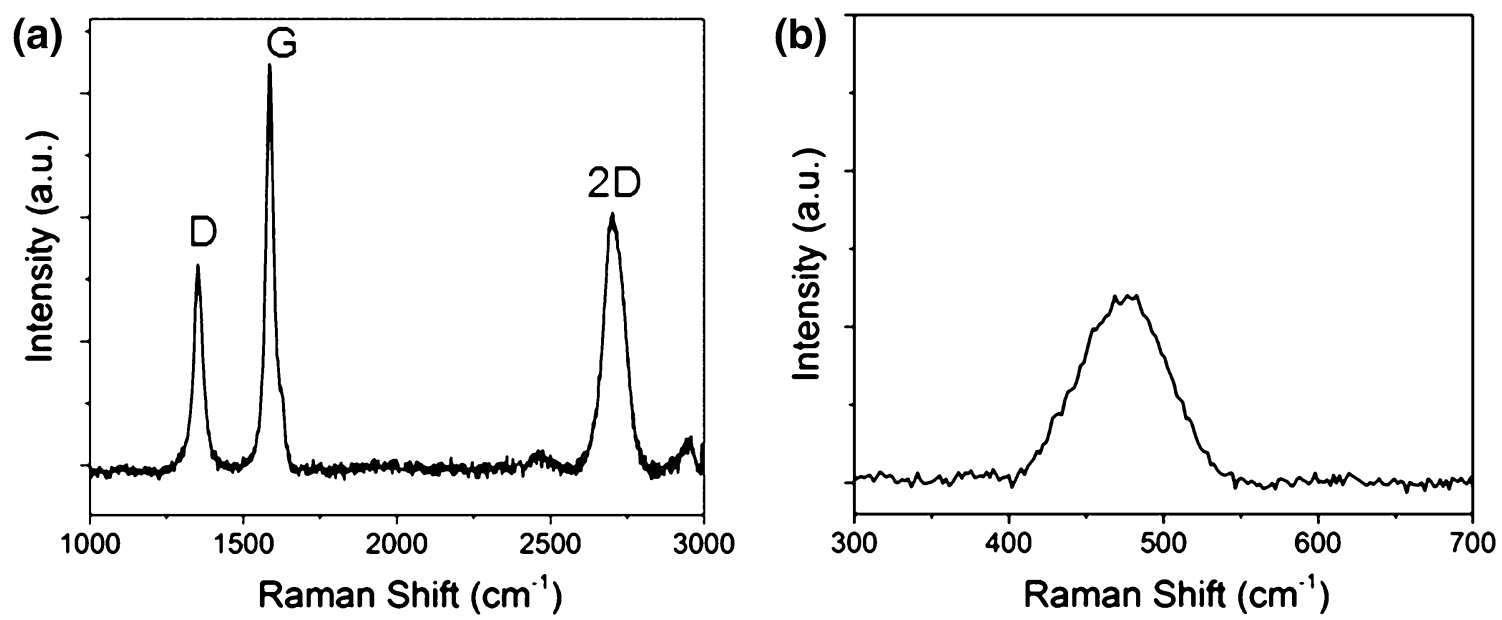

Fig. 11 Raman spectra of MLG (a) and Si (b) in a post-cycled MLG-Si anode. These spectra were taken after a total of 73 cycles under different rates as described in the text

due to species generated during cycling reactions involving the electrolyte $\left(\mathrm{LiPF}_{6}\right)$ and the solvents $(\mathrm{EC}, \mathrm{DEC})$, however, the exact identification of the specific chemical species is not yet established for this system.

In the as-deposited samples, deposition of $\mathrm{Si}$ over the MLG masked the Raman signal from MLG. However, after cycling, at locations where the Si had thinned or delaminated, a spectrum of the underlying MLG was measurable. The resulting Raman spectrum (Fig. 11a) was still representative of graphite, but indicated increased disorder in the D band of the post-cycled MLG relative to the asdeposited MLG (Fig. 2a), as a result of intercalation and deintercalation of $\mathrm{Li}$ between graphene layers during cycling. Raman spectra of a post-cycled PLD MLG-Si anode show only amorphous Si (Fig. 11b) at all probed locations, indicating a conversion of crystalline $\mathrm{Si}$ into amorphous $\mathrm{Si}$ as a result of cycling.

Further optimization of the MLG-PLD $\mathrm{Si}$ films for improved electrochemical performance is underway. Substrate preparation with etching or plasma treatments could further improve adhesion of the Si films and post-treatment of the $\mathrm{Si}$ films could potentially reduce film stress. The PLD process can be optimized through other selections of laser wavelength and background gas/pressure. Furthermore, the ratios of the MLG and Si can be fine-tuned for optimum performance.

\section{Conclusions}

An anode system fabricated from pulsed laser deposited $\mathrm{Si}$ on CVD-grown graphene layers $(\sim 23 \mathrm{~nm})$ on porous $\mathrm{Ni}$ foam substrates was electrochemically characterized and compared with Si-only anodes. TEM and Raman spectra showed that the $\mathrm{Si}$ films were a mixture of amorphous and crystalline $\mathrm{Si}$. Cyclic voltammograms showed the participation of MLG in the intercalation and deintercalation of $\mathrm{Li}$, however, it can be seen that $\mathrm{Si}$ is the dominant electrochemical component. Galvanostatic cycling clearly shows that the MLG-Si anodes show less capacity fade during cycling than Si-only anodes. FESEM images and EDS analyses following 73 cycles reveal severe delamination of $\mathrm{Si}$ in the Si-only anodes. After cycling, Raman spectra reveal only amorphous Si signatures with no evidence of crystalline $\mathrm{Si}$. Even under extreme cycling conditions $(0.01-3.0 \mathrm{~V} ; \mathrm{C} / 2)$, the MLG$\mathrm{Si}$ anodes show better cycle life and capacity. It was shown that cycling life can be extended by a combination of using MLG and cycling only between 0.05 and $1.0 \mathrm{~V}$. Under these conditions, stable average specific capacities of $\sim 1,200 \mathrm{mAh} / \mathrm{g}$ per total weight of MLG $+\mathrm{Si}$, over 80 cycles at $\mathrm{C} / 5$ rate, were obtained for the MLG-PLD $\mathrm{Si}$ anode. Detailed cycling characterization shows substantially improved stability for the MLG-Si anodes, under all conditions and in all stages. The combination of growth techniques and film layers described here offers the potential for an alternative route for addressing volume expansion problems of $\mathrm{Si}$ anodes. MLG appears to increase adhesion and provides a conductive and compliant buffer against volume expansion of the brittle $\mathrm{Si}$, thereby stabilizing the system.

Acknowledgments This work was funded by The Aerospace Corporation's Independent Research and Development program. The authors thank Miles Brodie and Nathan Presser for preparing TEMFIB cross sections. Helpful discussions with Joanna D. Cardema and Jeanne M. McGraw are gratefully acknowledged.

Open Access This article is distributed under the terms of the Creative Commons Attribution License which permits any use, distribution, and reproduction in any medium, provided the original author(s) and the source are credited. 


\section{References}

1. M.N. Obrovac, L. Christensen, Electrochem. Solid State Lett. 7(5), A93 (2004)

2. J. Li, J.R. Dahn, J. Electrochem. Soc. 154(3), A156-A161 (2007)

3. T.D. Hatchard, J.R. Dahn, J. Electrochem. Soc. 151(6), A838A842 (2004)

4. M.N. Obrovac, L.J. Krause, J. Electrochem. Soc. 154(2), A103A108 (2007)

5. L.Y. Beaulieu, T.D. Hatchard, A. Bonakdarpour, M.D. Fleischauer, J.R. Dahn, J. Electrochem. Soc. 150(11), A1457-A1464 (2003)

6. J.P. Maranchi, A.F. Hepp, P.N. Kumta, Electrochem. Solid State Lett. 6(9), A198-A201 (2003)

7. J. Graetz, C.C. Ahn, R. Yazami, B. Fultz, Electrochem. Solid State Lett. 6(9), A194-A197 (2003)

8. S. Ohara, J. Suzuki, K. Sekine, T. Takamura, J. Power Sources 119-121, 591-596 (2003)

9. T.L. Kulova, A.M. Skundin, Y.V. Pleskov, E.I. Terukov, O.I. Kon'kov, J. Electroanal. Chem. 600(1), 217-225 (2007)

10. K.-L. Lee, J.-Y. Jung, S.-W. Lee, H.-S. Moon, J.-W. Park, J. Power Sources 129(2), 270-274 (2004)

11. V.A. Sethuraman, K. Kowolik, V. Srinivasan, J. Power Sources 196(1), 393-398 (2011)

12. V.A. Sethuraman, V. Srinivasan, J. Newman, J. Electrochem. Soc. 160(2), A394-A403 (2012)

13. H. Wu, Y. Cui, Nano Today 7(5), 414-429 (2012)

14. C.K. Chan, R. Ruffo, S.S. Hong, R.A. Huggins, Y. Cui, J. Power Sources 189(1), 34-39 (2009)

15. C.K. Chan, H. Peng, G. Liu, K. McIlwrath, X.F. Zhang, R.A. Huggins, Y. Cui, Nat Nano 3(1), 31-35 (2008)

16. E. Quiroga-González, J. Carstensen, H. Föll, Electrochim. Acta 101, 93-98 (2013)

17. L.-F. Cui, R. Ruffo, C.K. Chan, H. Peng, Y. Cui, Nano Lett. 9(9), 491-495 (2009)
18. L.-F. Cui, Y. Yang, C.-M. Hsu, Y. Cui, Nano Lett. 9(9), 3370-3374 (2009)

19. M.W. Forney, R.A. DiLeo, A. Raisanen, M.J. Ganter, J.W. Staub, R.E. Rogers, R.D. Ridgley, B.J. Landi, J. Power Sources 228, 270-280 (2013)

20. H. Wu, G. Zheng, N. Liu, T.J. Carney, Y. Yang, Y. Cui, Nano Lett. 12(2), 904-909 (2012)

21. M. Thakur, S.L. Sinsabaugh, M.J. Isaacson, M.S. Wong, S.L. Biswal, Sci. Rep. 2, 795 (2012)

22. J. Luo, X. Zhao, J. Wu, H.D. Jang, H.H. Kung, J. Huang, J. Phys. Chem. Lett. 3(13), 1824-1829 (2012)

23. R.C. Guzman, J. Yang, M.M.-C. Cheng, S.O. Salley, K.Y. Simon Ng, J. Mater. Sci. 48(14), 4823-4833 (2013)

24. Y. Yao, M.T. McDowell, I. Ryu, H. Wu, N. Liu, L. Hu, W.D. Nix, Y. Cui, Nano Lett. 11(7), 2949-2954 (2011)

25. X. Zhou, Y.X. Yin, L.J. Wan, Y.G. Guo, Chem. Commun. (Camb.) 48(16), 2198-2200 (2012)

26. L. Ji, H. Zheng, A. Ismach, Z. Tan, S. Xun, E. Lin, V. Battaglia, V. Srinivasan, Y. Zhang, Nano Energy 1(1), 164-171 (2012)

27. Y.Q. Zhang, X.H. Xia, X.L. Wang, Y.J. Mai, S.J. Shi, Y.Y. Tang, C.G. Gu, J.P. Tu, J. Power Sources 213, 106-111 (2012)

28. K. Evanoff, A. Magasinski, J. Yang, G. Yushin, Adv. Energy Mater. 1(4), 495-498 (2011)

29. J. Ji, H. Ji, L.L. Zhang, X. Zhao, X. Bai, X. Fan, F. Zhang, R.S. Ruoff, Adv. Mater. 25(33), 4673-4677 (2013)

30. G. Radhakrishnan, P.M. Adams, B. Foran, M.V. Quinzio, M.J. Brodie, APL Mater. 1(6), 062103 (2013)

31. X. Liu, D. Wang, S. Shi, Electrochim. Acta 87, 865-871 (2013)

32. Q. Sa, Y. Wang, J. Power Sources 208, 46-51 (2012)

33. G. Radhakrishnan, P.M. Adams, A.D. Stapleton, H.G. Muller, B.J. Foran, Appl. Phys. A 105(1), 31-37 (2011)

34. G. Radhakrishnan, J.D. Cardema, P.M. Adams, H.I. Kim, B. Foran, J. Electrochem. Soc. 159(6), A752-A761 (2012)

35. M.D. Levi, E.A. Levi, D. Aurbach, J. Electroanal. Chem. 421, 89-97 (1997) 